\title{
Demographic Effects on Assets Selection and Debts of Chinese Urban Households
}

\author{
Huimin Xing \\ School of Finance \\ Zhejiang University of Finance and Economics, \\ Hangzhou, China \\ 398004341@qq.com
}

\author{
Jianhe Liu * \\ School of Finance \\ Zhejiang University of Finance and Economics, \\ Hangzhou, China \\ * Corresponding Author
}

\begin{abstract}
This paper uses household data of CHFS 2012 to discuss the demographic effects of Chinese urban families on the choice of assets and debts. We use the standard probit model to test the determinants of family's assets and liabilities and the Tobit model to analyze the determinants of the amount of household assets and liabilities. The independent variables of the models mainly include family population, and family head's age, gender, education level, health, party, ethnic and etc. According to results of regression analysis, family head's age is negatively related to debts; the education level and income of family head, and family population, etc. are positively related to family assets and debts; the ethnic and family assets show a significant negative correlation.
\end{abstract}

Keywords-Demographic Effects; Chinese Urban Household; Assets; Debts; Assets Choice; Household Head

\section{INTRODUCTION}

The financial crisis in 2008 and European debt crisis in 2011 shook the stability of the global financial markets. They have brought great negative impacts on the international capital market, and the global economy is difficult to recover in a short term. Governments take some policies to stimulate the economy. This surround conditions make some adjustments of family's asset allocation and liabilities, including Chinese households. In addition, China is the largest developing country in the world and the second largest economy. China increases her influence power and shows her impacts on international affairs. So, what about assets selection and debts of Chinese house-hold? How do Chinese households invest across all categories of assets? What factors affect Chinese household assets choice decision? What are the impacts of demographic effects on Chinese households' assets selections and debts? Although there are many achievements of assets selection and debts, not many scholars study these questions. We want to fill this gap and use household data of CHFS 2012 to show demographic effects on household assets selection and debts in China.

The remainder of this paper is set out as follows: Section 2 is literature review, we detail literature of demographic effects on household assets selection and debts; section 3 is data source and variable selection, we explain the data source and the variable selection; section 4 gives the calculation results and section 5 the conclusion.

\section{LITERATURE REVIEW}

How do households invest across all categories of assets? What factors affect household assets choice decision? Besides wealth effects, Campbell (2006) thinks that demographic characteristics have effects on the household assets choice decisions.

\section{A. Household Assets Selection}

Household characteristics have effects on assets selection, such as age (McCarthy, 2004; Yao and Zhang, 2005; Brown and Taylor,2008;Merry and Thoma,2014), education (Brown and Taylor, 2008; McCarthy, 2004; Harness, Finke and Chatterjee, 2010), race (Harness, Finke and Chatterjee, 2010), residence (Arrondel and Lefebvre, 2001; Huang et al., 2013), and etc.

\section{B. Household Debts}

For most households, the debts include mortgage debt and consumer debt (the debts owed on credit cards and installment loans). Corresponding to the effects on asset selection, demographic effects are also one kind of important factors of household debts.

Similar to asset selection, many scholars believe that household characteristics also have effects on debts, such as age (Dunkelberg and Stafford, 1971; Yilmazer and DeVaney, 2005), education (Yilmazer and DeVaney, 2005), residence (Dunkelberg and Stafford, 1971), income (Davis, Kubler and Willen, 2006; Zinman, 2007) and etc.

All of these scholar's study US households or families in other developed countries. With the wealth accumulation of Chinese households, assets selection and debts of Chinese urban households deserve to be paid attention.

\section{DATA SOURCE AND VARIABLE SELECTION}

\section{A. Data Sources}

The empirical data of this paper comes from the China Household Finance Survey (CHFS), which is based at Southwestern University of Finance and Economics. The survey project mainly includes the micro data of family finance, including housing assets and household wealth, the situation of debt, the structure of income and consumption, the structure of household assets, family characteristics and employment. 
The main purpose of this paper is to analyze the demographic effects on Chinese urban household assets and debts, so the variables involved in this paper mainly include household assets, household debt and family demographic characteristics.

As can be seen from table I, the average age of the urban household heads of the sample is about 50 years old, distributed between 4 to 99 years old. The average age of the households is about 12 years, that is, high school or technical secondary school education. The average household population is 3 , which show the typical urban family in mainland China, parents and one child. In the sample, the average household income is 71141.25 yuan, the value of average urban household assets is 835267.90 yuan, but that of financial assets is only 86093.96 yuan. Total assets of urban family are far greater than the financial assets, there are two possible reasons: the urban housing value is very high in china, and urban families don't invest a lot in financial assets. Comparatively speaking, the level of urban household debt in China is relatively low, the average household debt is 48475.24 yuan, it is a really small number comparing to the assets. In order to further understand the basic data of urban family assets, the structure of family assets and liabilities is described in Table 2.

TABLE I. VARIABLE DESCRIPTIVE STATISTIC

\begin{tabular}{ccccc}
\hline Variables & Mean & $\begin{array}{c}\text { Standard } \\
\text { deviation }\end{array}$ & Max & Min \\
\hline Age & 49.68 & 14.72 & 99 & 4 \\
Education years & 11.37 & 3.90 & 21 & 0 \\
Population & 3.05 & 1.26 & 13 & 1 \\
Family income & 71141.25 & 172032.57 & 3000000 & -491000 \\
Family financial & 86093.96 & 264377.84 & 6008000 & 0 \\
assets & & & & 0 \\
Total assets & 835267.90 & 1346728.81 & 13600400 & 0 \\
Total debts & 48475.24 & 255145.34 & 5700500 & 0 \\
\hline
\end{tabular}

As the data shown in table II, bank deposits are the most important family financial assets and accounts for $48.88 \%$ of total financial assets. But the ratio of stocks and other risky assets is very low, which means that not many urban households participate in the risk asset market. There are $88.86 \%$ families owning houses and house is the most important category of non-financial assets. The proportion of household durable goods and other nonfinancial assets are relatively low. Real estate liability is the main household debt, accounting for $63.4 \%$ of urban family debts, followed by the industry and commercial loans, which accounts for $24.15 \%$. The ratios of other liabilities are too low to pay attention.
TABLE II. URBAN HOUSEHOLD ASSETS-LIABILITY STRUCTUR

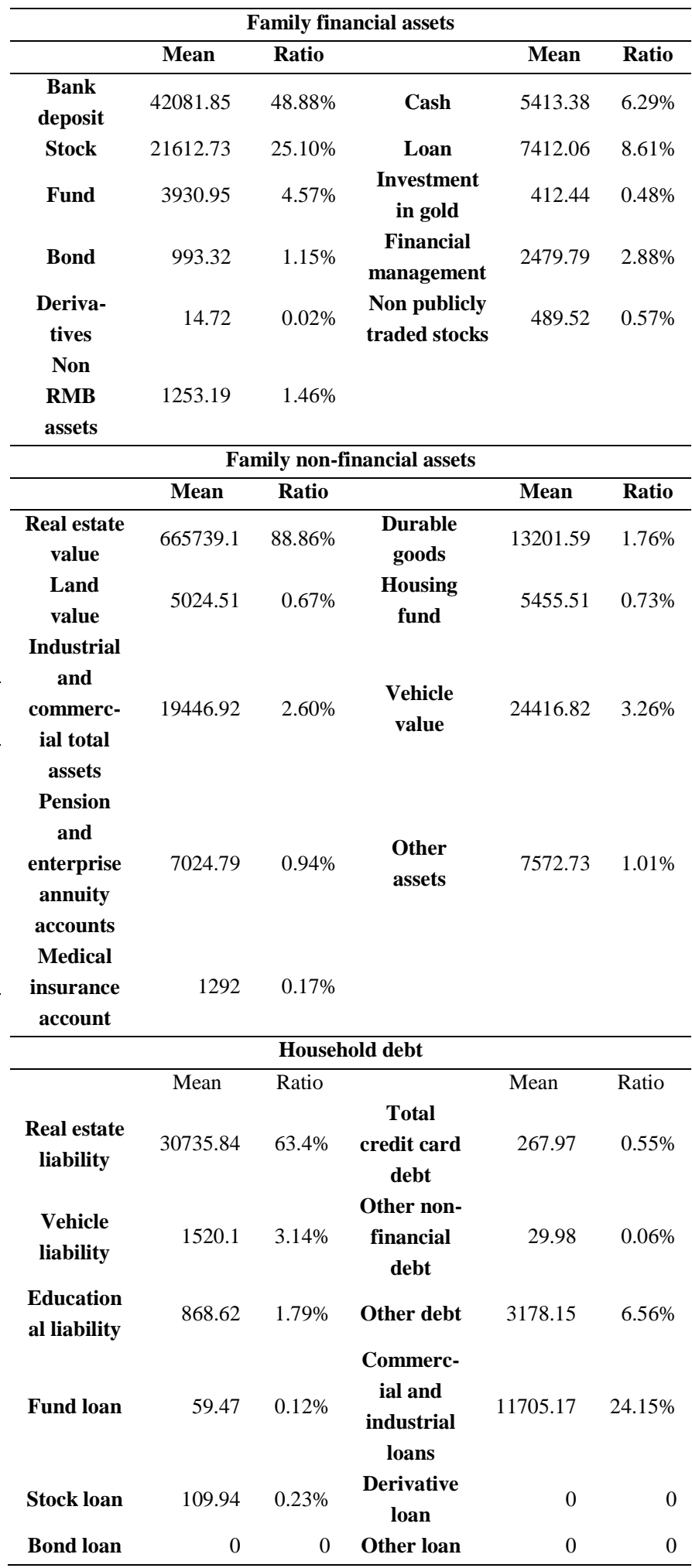

B. Selection of Independent Variables

We select the independent variables of the model: household population, and some characteristics of household head, such as age, gender, education level, marital status, income, health, party, and ethnic, etc. 
Age and age $^{2}$ : respectively represent age and the square age of the household head. Age $^{2}$ is introduced to find the nonlinear relationship between age and assets or debt.

Gender: this indicator is a gender dummy variable, which is 0 for males, 1 for females.

Edu: the education level is divided by years of education. "Bachelor degree and above" is 16 years, "College" is 14 years; "secondary school" is 12 years; "junior high school" is 9 years; "primary school" is 6 years.

Married: there are six kinds of marital status, married, unmarried, divorced, widowed, cohabitation, separation, etc. married $=1$ means that borrowers are in marital status. Married $=0$ means in other conditions.

Health: if household is healthy, health $=1$, or health $=0$.

Ethnic: if the ethnic of urban household head is Han, ethnic $=1$, or ethnic $=0$.

Party: if household head is Chinese communist party member, party $=1$, or party $=0$.

From the perspective of family choices, there are two kinds of variables: ownerships of family assets and liabilities, the amounts of assets and liabilities. Therefore, this paper will use the probit model and the Tobit model to study the determinants of Chinese urban household assets and liabilities.

\section{EMPIRICAL TEST}

\section{A. Determinants of Household Assets and Liabilities}

We use the standard probit model to test the determinants of the family's assets and liabilities. The Probit model form is as equation (1).

$$
\begin{aligned}
& y_{i}^{*}=x_{i} \beta+u_{i} \\
& y_{i}= \begin{cases}1 & y_{i}^{*}>0 \\
0 & y_{i}^{*} \leq 0\end{cases}
\end{aligned}
$$

Among them, $y_{i}^{*}$ represents the willingness to hold the assets or liabilities of the family, $y_{i}$ is a dummy variable representing the amount of assets or liabilities held by urban households. When $y_{i}^{*}>0$, the family will hold assets or liabilities; When $y_{i}^{*} \leq 0$, the families do not want to hold assets or liabilities, and the ownership of its assets or liabilities is $0, y_{i}=0 . x_{i}$ represents factor that affect household assets or liabilities. The control variables include sex, marriage, Communist Party members, nationality, religion, occupation, health status, family income, family population, etc.
TABLE III DETERMINANTS OF THE CHOICE OF HOUSEHOLD ASSETS ABD LIABILITIES: PROBIT REGRESSION

\begin{tabular}{|c|c|c|}
\hline Variables & Assets ownership & Debt ownership \\
\hline \multirow[t]{2}{*}{ age } & $-0.119 * *$ & 0.0171 \\
\hline & $(0.0484)$ & $(0.0113)$ \\
\hline \multirow[t]{2}{*}{ age $^{2}$} & $0.000730 * *$ & $-0.000458 * * *$ \\
\hline & $(0.000291)$ & (0.000116) \\
\hline \multirow[t]{2}{*}{ edu } & 0.0126 & $0.0186^{* * *}$ \\
\hline & $(0.0647)$ & $(0.00692)$ \\
\hline \multirow[t]{2}{*}{ health } & - & -0.0591 \\
\hline & & $(0.0464)$ \\
\hline \multirow[t]{2}{*}{ pop } & -0.0379 & $0.140 * * *$ \\
\hline & $(0.120)$ & $(0.0193)$ \\
\hline \multirow[t]{2}{*}{ gender } & $-0.353 * *$ & 0.0343 \\
\hline & $(0.141)$ & $(0.0468)$ \\
\hline \multirow[t]{2}{*}{ married } & -0.0304 & $-0.122 *$ \\
\hline & $(0.357)$ & $(0.0689)$ \\
\hline \multirow[t]{2}{*}{ o. party } & - & $0.136 * *$ \\
\hline & & $(0.0549)$ \\
\hline \multirow[t]{2}{*}{ o. ethnic } & - & -0.0735 \\
\hline & & (0.0819) \\
\hline \multirow[t]{2}{*}{ inc } & 0.0200 & 0.00174 \\
\hline & $(0.0224)$ & $(0.00127)$ \\
\hline \multirow[t]{2}{*}{ Constant } & $7.499 * * *$ & $-0.701 * *$ \\
\hline & $(2.443)$ & $(0.287)$ \\
\hline Observations & 4,001 & 4,001 \\
\hline
\end{tabular}
RESULTS

Note: robust standard errors in parentheses; $* * *$ means significance at 0.01 level, $* *$ means significance at 005 level, * means significance at 0.1 level.

The results in Table III show that age is a positive factor to urban household debt, and the negative factor to family assets. This is consistent with the life cycle theory. Education level of household head is the positive factor to household debt ownership, the more years of education household head has, the higher possibility the household holds debt. But years of education have no significant effects on family property. There is no direct linkage between health status and household assets or liabilities. Population is negative to assets and positive to debt. The less the urban household size is, the more debts are owned. Larger household population leads to more debts and more consumption. The effect of income is not significant.

\section{B. Determinants of the Amounts of Household Assets and Liabilities}

For further understanding the determinants of household assets and liability, we analyze the determinants of the amount of household assets and liabilities. In the sample, many households' assets or liabilities equal to 0 , showing that the explanatory variables are truncated. We generally use the Tobit model to carry out regression analysis for truncated explanatory variables. The Tobit model is as equation (2).

$$
\begin{aligned}
& y_{i}^{*}=x_{i} \beta+u_{i} \\
& y_{i}= \begin{cases}y_{i}^{*} & y_{i}^{*}>0 \\
0 & y_{i}^{*} \leq 0\end{cases}
\end{aligned}
$$


Similar to Probit model, $y_{i}^{*}$ is the ownership of household assets or liabilities; $x_{i}$ is a variable that affects the value of the family's assets or liabilities. Different from the Probit model, $y_{i}$ is the real amount of household assets or liabilities. When $y_{i}^{*} \succ 0$, the real amount of household assets or liabilities is $y_{i}^{*}$, and $y_{i}=y_{i}^{*}$; When $y_{i}^{*} \leq 0$, families do not want to hold assets or liabilities, the amount of household assets or liabilities is $0, y_{i}=0$.

TABLE IV. DETERMINANTS OF THE NUMBER OF HOUSEHOLD ASSETS ABD LIABILITIES: TOBIT REGRESSION RESULTS

\begin{tabular}{|c|c|c|}
\hline Variables & $\begin{array}{c}\text { Amount of household } \\
\text { assets }\end{array}$ & $\begin{array}{c}\text { Amount of household } \\
\text { debts }\end{array}$ \\
\hline \multirow[t]{2}{*}{ age } & 1.155 & 0.476 \\
\hline & $(0.815)$ & $(0.469)$ \\
\hline \multirow[t]{2}{*}{ age $^{2}$} & -0.00394 & $-0.0157 * * *$ \\
\hline & $(0.00771)$ & $(0.00478)$ \\
\hline \multirow[t]{2}{*}{ edu } & $6.265^{* * *}$ & $1.355 * * *$ \\
\hline & $(0.573)$ & $(0.305)$ \\
\hline \multirow[t]{2}{*}{ health } & $16.30 * * *$ & $-3.524 *$ \\
\hline & $(4.128)$ & (2.087) \\
\hline \multirow[t]{2}{*}{ pop } & $7.288 * * *$ & $5.882 * * *$ \\
\hline & $(1.671)$ & $(0.852)$ \\
\hline \multirow[t]{2}{*}{ gender } & $14.40 * * *$ & 0.422 \\
\hline & $(4.179)$ & (2.096) \\
\hline \multirow[t]{2}{*}{ married } & -8.415 & $-7.510 * *$ \\
\hline & $(5.910)$ & $(3.066)$ \\
\hline \multirow[t]{2}{*}{ party } & -2.907 & $5.218^{* *}$ \\
\hline & (4.849) & $(2.455)$ \\
\hline \multirow[t]{2}{*}{ ethnic } & $-24.79 * * *$ & -4.150 \\
\hline & (7.188) & $(3.608)$ \\
\hline \multirow[t]{2}{*}{ inc } & $3.176^{* * *}$ & $0.456 * * *$ \\
\hline & $(0.113)$ & $(0.0470)$ \\
\hline \multirow[t]{2}{*}{ Constant } & $-58.15^{* * *}$ & $-42.95 * * *$ \\
\hline & $(22.52)$ & (12.03) \\
\hline Observations & 4,001 & 4,001 \\
\hline
\end{tabular}

Note: standard errors in parentheses; $* * *$ means significance at 0.0 level, $* *$ means significance at 005 level, $*$ means significance at 0.1 level.

From the regression results, we can see that the years of education of family head and family assets, liabilities are positively correlated. The higher the income is, the higher the assets and liabilities are. Family population is positive to the amounts of assets and liabilities. Education experience, high income and family population make household head to hold more assets and debt.

The healthier family head is, the more assets and the less liability the household has. The healthy status of household head is helpful for household to hold more assets and less debt.

Family head age is negative to debts, but the effect of age on assets isn't significant. Household head gender is positively correlated to household assets, but not significantly related to the amount of debt. The female household head and elder household head are likely to hold more assets and less debt.

There is a negative correlation between the ethnic and family assets and debt. But the linkage between the ethnicity and family debt is not significant.

\section{CONCLUSION}

According to the empirical study on the influence factors of assets and liabilities, it is easy to find that family demographic factors have impacts on Chinese household assets selection, liabilities, and the amount of assets and liabilities. Age and gender of household head are important factors of family assets choice. Age, family population and the years of education have important impacts on family debt decision. The family population, education, health status, gender of household head and household income have significant impacts on the the amount of assets holding. Age, family population, years of education, marital status of household head and household income, all these have significant impacts on debt holding. Health status, race and ethnicity have no effects on the choice of family assets.

From the empirical analysis of this paper, we can know that the families with high income have relatively high debt levels. This shows that family income level will restrict the family's debt, the lack of confidence in the future of household income will result in social resource allocation imbalance. It also shows that household debt has a certain leverage effect. The higher income families are more willing to hold debt, such as mortgage. Because of the rapid rise in housing prices, the net assets of households with debt continue to rise, the net asset and liability ratio becomes larger and larger. Lacking in the ability to hold debt, household income and wealth will fall and the gap between the rich and the poor will expand. Therefore, we must reform the income distribution system and increase the income of the family, especially lowincome families and rural families. Besides, the empirical analysis shows that if the family head is highly educated, the household will hold more debt which leads to lower net assets and liabilities ratio. So improving the education level of the household members is a good way for the balance of social resources allocation.

\section{ACKNOWLEDGMENT}

This paper is sponsored by Zhejiang Xinmiao Talents Program (No.2015R414035) and Zhejiang Provincial Natural Science Foundation (No. Y16G030044 and LY14G030013).

\section{PREFERENCE}

[1] D.Mccarthy.Household Portfolio Allocation:A Review of the Literature[R].Imperial College Working Paper.2004.

[2] Yao R, Zhang H H. Optimal consumption and portfolio choices with risky housing and borrowing constraints[J]. Review of Financial Studies. 2005, pp.197-239.

[3] Brown, $\mathrm{S}$ and Taylor,K. Household debt and financial assets:evidence from Germany.Great Britain and the USA [J].Royal Statistical Society.J.R.Statist.Soe.2008,pp.615-643.

[4] Merry, Ellen A.;and Thomas, Logan. Asset Holdings of Young Households: Trends and Patterns [J].Federal Reserve Bank of St. Louis Review.2014:391-411. 
[5] Harness, N., Finke, M., \& Chatterjee, S.The effects of the capital accumulation ratio on wealth[J]. Journal of Financial Counseling and Planning. 2009b,20(1).pp.44-57.

[6] Arrondel L, Lefebvre B. Consumption and investment motives in housing wealth accumulation: a French study[J]. Journal of Urban Economics, 2001,50(1). pp.112-137.

[7] Dunkelberg, W., \&Stafford,F. Debt in the consumer portfolio: Evidence from a panel study[J].American Economic Review,1971(61).pp.598-613.
[8] Yilmazer,t.,and de vaney,s.a..Household debt over the life cycle[J].Financial services review,2005,14(4).pp.285-304.

[9] Davis,S.J., F.Kubler, and P.Willen.Borrowing Costs and the Demand for Equity over the Life Cycle[J].Review of Economics and Statistics.2006(88).pp.348-362.

[10] Zinman,J. Household Borrowing High and Lending Low Under No-Arbitrage[R].Working paper,Dartmouth College.2007. 